\title{
Metabolite Profiling of Eastern Teaberry (Gaultheria procumbens L.) Lipophilic Leaf Extracts with Hyaluronidase and Lipoxygenase Inhibitory Activity
}

\author{
Piotr Michel ${ }^{1, *}$, Aleksandra Owczarek ${ }^{1}$, Magdalena Matczak ${ }^{1}$, Martyna Kosno ${ }^{1}$, \\ Paweł Szymański ${ }^{2}$, Elżbieta Mikiciuk-Olasik ${ }^{2}$, Anna Kilanowicz ${ }^{3}$, Wiktor Wesołowski ${ }^{3}$ \\ and Monika A. Olszewska ${ }^{1}$ \\ 1 Department of Pharmacognosy, Faculty of Pharmacy, Medical University of Lodz, 1 Muszynskiego, \\ 90-151 Lodz, Poland; aleksandra.owczarek@umed.lodz.pl (A.O.); magdalena.matczak@umed.lodz.pl (M.M.); \\ kosno.martyna@gmail.com (M.K.); monika.olszewska@umed.lodz.pl (M.A.O.) \\ 2 Department of Pharmaceutical Chemistry, Drug Analyses and Radiopharmacy, Medical University of Lodz, \\ 1 Muszynskiego, 90-151 Lodz, Poland; pawel.szymanski@umed.lodz.pl (P.S.); \\ elzbieta.mikiciuk-olasik@umed.lodz.pl (E.M.-O.) \\ 3 Department of Toxicology, Faculty of Pharmacy, Medical University of Lodz, 1 Muszynskiego, 90-151 Lodz, \\ Poland; anna.kilanowicz@umed.lodz.pl (A.K.); wiktor.wesolowski@umed.lodz.pl (W.W.) \\ * Correspondence: piotr.michel@umed.lodz.pl; Tel.: +48-42-677-91-69
}

Academic Editor: Thomas J. Schmidt

Received: 25 January 2017; Accepted: 2 March 2017; Published: 6 March 2017

\begin{abstract}
The phytochemical profile and anti-inflammatory activity of Gaultheria procumbens dry lipophilic leaf extracts were evaluated. Forty compounds were identified by GC-MS, representing $86.36 \%$ and $81.97 \%$ of the petroleum ether (PE) and chloroform (CHE) extracts, respectively, with ursolic acid $(28.82 \%)$, oleanolic acid $(10.11 \%)$, methyl benzoate $(10.03 \%)$, and methyl salicylate $(6.88 \%)$ dominating in CHE, and methyl benzoate (21.59\%), docosane $(18.86 \%)$, and octacosane $(11.72 \%)$ prevailing in PE. Three components of CHE were fully identified after flash chromatography isolation and spectroscopic studies as $(6 S, 9 R)$-vomifoliol $(4.35 \%)$, 8-demethyl-latifolin $(1.13 \%)$, and 8-demethylsideroxylin (2.25\%). Hyaluronidase and lipoxygenase inhibitory activity was tested for CHE $\left(\mathrm{IC}_{50}=282.15 \pm 10.38 \mu \mathrm{g} / \mathrm{mL}\right.$ and $899.97 \pm 31.17 \mu \mathrm{g} / \mathrm{mL}$, respectively), PE $\left(\mathrm{IC}_{50}=401.82 \pm 16.12 \mu \mathrm{g} / \mathrm{mL}\right.$ and $\left.738.49 \pm 15.92 \mu \mathrm{g} / \mathrm{mL}\right)$, and nine of the main constituents versus heparin $\left(\mathrm{IC}_{50}=366.24 \pm 14.72 \mu \mathrm{g} / \mathrm{mL}\right)$ and indomethacin $\left(\mathrm{IC}_{50}=92.60 \pm 3.71 \mu \mathrm{g} / \mathrm{mL}\right)$ as positive controls. With the best activity/concentration relationships, ursolic and oleanolic acids were recommended as analytical markers for the extracts and plant material. Seasonal variation of both markers following foliar development was investigated by UHPLC-PDA. The highest levels of ursolic (5.36-5.87 mg/g DW of the leaves) and oleanolic (1.14-1.26 mg/g DW) acids were observed between August and October, indicating the optimal season for harvesting.
\end{abstract}

Keywords: Gaultheria procumbens; leaves; lipophilic extracts; GC-MS; anti-inflammatory activity; seasonal variation

\section{Introduction}

Gaultheria procumbens L. (eastern teaberry, checkerberry, American wintergreen, Ericaceae) is a small, low-growing, evergreen shrub native to northeastern North America and widely cultivated all through the Northern Hemisphere due to its ornamental and medicinal value. The most commonly used plant organs of G. procumbens are the leaves, traditionally valued as anti-inflammatory and 
analgesic agents as well as a source of wintergreen essential oil [1]. Methyl salicylate, constituting over $95 \%$ of the essential oil [2], and its glycosidic precursor-gaultherin [3] - are the main representatives of salicylates, so far considered as the primary active constituents of Gaultheria plants [4-6]. However, plant extracts are usually multicomponent and their activity is rarely due to one, single constituent. In fact, our previous studies [7] demonstrated that the anti-inflammatory activity of wintergreen leaves is also largely influenced by other polar compounds, among which thirty-five representatives of flavonoids, proanthocyanidins, and caffeoylquinic acids were identified by UHPLC-PDA-ESI-MS ${ }^{3}$ profiling. The concept of metabolite profiling evolved recently in the most preferable characterization procedure of bioactive plant fractions, but it is generally confined to hydrophilic compounds alone [8], while lipophilic components are often studied only fragmentarily, either by classic techniques such as isolation, or after separation of less complex, specific sub-fractions, e.g., essential oils. That is also the case of Gaultheria plants, in which the presence of several lipophilic constituents, such as pentacyclic triterpenes and sterols, was discovered in selected taxons (G. fragrantissima, G. nummularoides, G. paniculata, G. subcorymbosa, and G. yunnanensis) by standard (isolation) techniques [1,9-13]. More selective methods (GC-MS) have so far been used only for identification of long-chain aliphatic alkanes $C_{15}-C_{20}$ in leaf waxy layers of G. subcorymbosa and G. antipoda [14], and volatile fractions of various wintergreen species [1,2]. Some of the isolated non-volatile molecules, including pentacyclic triterpene acids, like oleanolic and ursolic acids, isomeric triterpene alcohols, like $\alpha$ - and $\beta$-amyrins, as well as phytosterols with the ubiquitous $\beta$-sitosterol, are well-documented anti-inflammatory agents, active in certain in vitro and in vivo models [15-20]. Despite these facts, there is no comprehensive information available on the lipophilic profile of any Gaultheria plant and its possible impact on the anti-inflammatory activity of the respective plant materials. As qualitative and quantitative composition of specialized plant metabolites often depends strongly on numerous factors, among which stage of the phenological cycle is one of the most important [21,22], seasonal dynamics in biosynthesis of the primary lipophilic components could also significantly influence the final biological value of Gaultheria plants and their reasonable harvest. However, also this issue remains undiscovered for wintergreen species.

Thus, the aim of this research was to determine the phytochemical profile and anti-inflammatory activity of dry lipophilic (petroleum ether and chloroform) extracts of G. procumbens leaves. The qualitative profile of the extracts was first monitored by GC-MS. Next, the preparative liquid column chromatography, followed by spectroscopic (ESI-MS, UV-Vis, IR, 1D and 2D NMR) studies, was performed for full structural characterization of some problematic analytes. Two in vitro tests measuring the inhibitory effects on pro-inflammatory enzymes, i.e., lipoxygenase and hyaluronidase, were selected as anti-inflammatory activity models, based on the previous findings for dry hydrophilic leaf extracts of wintergreen [7]. Finally, the seasonal variations in the content of two dominant lipophilic biomolecules, i.e., ursolic and oleanolic acids, in the leaf samples of G. procumbens were monitored throughout the growing season by UHPLC-PDA.

\section{Results and Discussion}

\subsection{Qualitative Profiling of G. procumbens Dry Lipophilic Leaf Extracts}

The qualitative characteristics of the wintergreen leaf lipophilic compounds were evaluated by GC-MS analysis of the dry petroleum ether (PE) and chloroform (CHE) extracts after trimethylsilyl derivatization. The main identification data of all detected peaks and the representative GC chromatograms of PE and CHE are presented in Table 1 and Figures S1 and S2, respectively (for full data see Table S1). 
Table 1. GC-MS data of identified constituents in the G. procumbens dry lipophilic leaf extracts.

\begin{tabular}{|c|c|c|c|c|c|c|c|}
\hline \multirow{2}{*}{ No. } & \multirow{2}{*}{ Compound } & \multirow{2}{*}{$\mathbf{R}_{t}{ }^{a}$} & \multicolumn{2}{|c|}{ Molecular } & \multirow{2}{*}{$Q^{\mathbf{b}}$} & \multicolumn{2}{|c|}{ Relative Content (\%) } \\
\hline & & & Weight & Formula & & $P^{c}$ & CHE $^{d}$ \\
\hline 1 & methyl salicylate $(\mathbf{S M}){ }^{\mathrm{e}}$ & 7.84 & 152 & $\mathrm{C}_{8} \mathrm{H}_{8} \mathrm{O}_{3}$ & 100 & 2.31 & 6.88 \\
\hline 2 & trimethylsilanol g & 9.01 & 90 & $\mathrm{C}_{3} \mathrm{H}_{10} \mathrm{OSi}$ & 99 & 0.86 & \\
\hline 3 & methyl benzoate $(\mathbf{B M})^{\mathrm{g}}$ & 10.53 & 136 & $\mathrm{C}_{8} \mathrm{H}_{8} \mathrm{O}_{2}$ & 91 & 21.59 & 10.03 \\
\hline 4 & 4-hydroxyphenylethanol g & 12.07 & 456 & $\mathrm{C}_{8} \mathrm{H}_{10} \mathrm{O}_{2}$ & 99 & & 2.78 \\
\hline 5 & $n$-dodecanoic acid (lauric acid) $\mathrm{g}$ & 12.61 & 200 & $\mathrm{C}_{12} \mathrm{H}_{24} \mathrm{O}_{2}$ & 99 & 0.32 & \\
\hline 6 & $m$-methoxybenzoic acid ( $m$-anisic acid) $\mathrm{g}$ & 13.39 & 152 & $\mathrm{C}_{8} \mathrm{H}_{8} \mathrm{O}_{3}$ & 98 & & 3.60 \\
\hline 7 & $(6 S, 9 R)$-vomifoliol $(\text { VO })^{\mathrm{e}}$ & 13.72 & 220 & $\mathrm{C}_{13} \mathrm{H}_{20} \mathrm{O}_{3}$ & 100 & & 4.35 \\
\hline 8 & neophytadiene $\mathrm{g}$ & 13.79 & 278 & $\mathrm{C}_{20} \mathrm{H}_{38}$ & 99 & 3.44 & 5.36 \\
\hline 9 & $n$-hexadecanoic acid (palmitic acid) $\mathrm{g}$ & 14.86 & 256 & $\mathrm{C}_{18} \mathrm{H}_{36} \mathrm{O}_{2}$ & 99 & 1.42 & 2.19 \\
\hline 10 & phytol $\mathrm{g}$ & 15.49 & 296 & $\mathrm{C}_{20} \mathrm{H}_{40} \mathrm{O}$ & 98 & 0.69 & \\
\hline 11 & $n$-octadecanoic acid (stearinic acid) $\mathrm{g}$ & 15.79 & 284 & $\mathrm{C}_{18} \mathrm{H}_{36} \mathrm{O}_{2}$ & 96 & 0.21 & \\
\hline 12 & pentacosane $\mathrm{g}$ & 16.86 & 352 & $\mathrm{C}_{25} \mathrm{H}_{52}$ & 99 & 0.48 & \\
\hline 13 & heneicosane $\mathrm{g}$ & 17.25 & 296 & $\mathrm{C}_{21} \mathrm{H}_{44}$ & 97 & 0.34 & \\
\hline 14 & $n$-docosanoic acid (behenic acid) $g$ & 17.42 & 340 & $\mathrm{C}_{22} \mathrm{H}_{44} \mathrm{O}_{2}$ & 94 & 0.19 & \\
\hline 15 & heptacosane $\mathrm{g}$ & 17.69 & 380 & $\mathrm{C}_{27} \mathrm{H}_{56}$ & 99 & 2.40 & \\
\hline 16 & tetracosan-1-ol g & 17.89 & 354 & $\mathrm{C}_{24} \mathrm{H}_{40} \mathrm{O}$ & 98 & 0.06 & \\
\hline 17 & hexacos-1-ene $\mathrm{g}$ & 18.14 & 364 & $\mathrm{C}_{26} \mathrm{H}_{52}$ & 93 & 2.14 & \\
\hline 18 & 13-docosenamide (erucamide) $\mathrm{g}$ & 18.15 & 337 & $\mathrm{C}_{22} \mathrm{H}_{43} \mathrm{NO}$ & 97 & & 3.43 \\
\hline 19 & $n$-tetracosanoic acid (lignoceric acid) $\mathrm{g}$ & 18.35 & 368 & $\mathrm{C}_{24} \mathrm{H}_{48} \mathrm{O}_{2}$ & 99 & 0.02 & \\
\hline 20 & squalene $\mathrm{g}$ & 18.38 & 410 & $\mathrm{C}_{30} \mathrm{H}_{50}$ & 99 & 0.53 & \\
\hline 21 & tetracosane $\mathrm{g}^{\mathrm{g}}$ & 18.69 & 278 & $\mathrm{C}_{24} \mathrm{H}_{50}$ & 94 & & 0.38 \\
\hline 22 & octacosane $\mathrm{g}$ & 18.73 & 394 & $\mathrm{C}_{28} \mathrm{H}_{58}$ & 99 & 11.72 & \\
\hline 23 & hexacosan-1-ol g & 18.96 & 382 & $\mathrm{C}_{26} \mathrm{H}_{54} \mathrm{O}$ & 90 & 0.31 & \\
\hline 24 & hexadecane ${ }^{g}$ & 19.31 & 226 & $\mathrm{C}_{16} \mathrm{H}_{34}$ & 95 & 1.62 & \\
\hline 25 & nonacosane $\mathrm{g}$ & 20.03 & 278 & $\mathrm{C}_{29} \mathrm{H}_{60}$ & 96 & & 0.66 \\
\hline 26 & 8-demethyllatifolin (DL) ${ }^{\mathrm{e}}$ & 20.12 & 328 & $\mathrm{C}_{18} \mathrm{H}_{16} \mathrm{O}_{6}$ & 100 & & 1.13 \\
\hline 27 & docosane (DOC) ${ }^{g}$ & 20.14 & 310 & $\mathrm{C}_{22} \mathrm{H}_{46}$ & 100 & 18.86 & \\
\hline 28 & heptacosan-1-ol g & 20.24 & 396 & $\mathrm{C}_{27} \mathrm{H}_{56} \mathrm{O}$ & 94 & 0.05 & \\
\hline 29 & octacosan-1-ol g & 20.39 & 410 & $\mathrm{C}_{28} \mathrm{H}_{58} \mathrm{O}$ & 91 & 0.28 & \\
\hline 30 & stigmasta-3,5-diene ${ }^{g}$ & 20.51 & 396 & $\mathrm{C}_{29} \mathrm{H}_{48}$ & 90 & 0.11 & \\
\hline 31 & $\alpha$-tocopherol ${ }^{g}$ & 20.60 & 430 & $\mathrm{C}_{29} \mathrm{H}_{50} \mathrm{O}_{2}$ & 99 & 0.27 & \\
\hline 32 & 8-demethylsideroxylin (DS) e & 20.89 & 298 & $\mathrm{C}_{17} \mathrm{H}_{14} \mathrm{O}_{5}$ & 100 & & 2.25 \\
\hline 33 & $n$-hexacosanoic acid (cerotic acid) $\mathrm{g}$ & 21.27 & 396 & $\mathrm{C}_{26} \mathrm{H}_{52} \mathrm{O}_{2}$ & 90 & 0.18 & \\
\hline 34 & tritriacontane $\mathrm{g}$ & 21.96 & 464 & $\mathrm{C}_{33} \mathrm{H}_{68}$ & 98 & 2.46 & \\
\hline 35 & campesterol $\mathrm{g}$ & 22.01 & 400 & $\mathrm{C}_{28} \mathrm{H}_{48} \mathrm{O}$ & 97 & 0.01 & \\
\hline 36 & $\beta$-sitosterol $(\beta \text {-SIT })^{g}$ & 23.08 & 414 & $\mathrm{C}_{29} \mathrm{H}_{50} \mathrm{O}$ & 100 & 2.68 & \\
\hline 37 & $\beta$-amyrin $\mathrm{f}$ & 23.35 & 426 & $\mathrm{C}_{30} \mathrm{H}_{50} \mathrm{O}$ & 100 & 0.98 & \\
\hline 38 & $\alpha$-amyrin ${ }^{\mathrm{f}}$ & 23.89 & 426 & $\mathrm{C}_{30} \mathrm{H}_{50} \mathrm{O}$ & 100 & 3.86 & \\
\hline 39 & oleanolic acid $(\mathbf{O A})^{\mathrm{e}}$ & 26.72 & 456 & $\mathrm{C}_{30} \mathrm{H}_{48} \mathrm{O}_{3}$ & 100 & 1.70 & 10.11 \\
\hline \multirow[t]{2}{*}{40} & ursolic acid (UA) ${ }^{\mathrm{e}}$ & 27.67 & 456 & $\mathrm{C}_{30} \mathrm{H}_{48} \mathrm{O}_{3}$ & 100 & 4.27 & 28.82 \\
\hline & & & & Total: & & 86.36 & 81.97 \\
\hline
\end{tabular}

${ }^{a} R_{\mathrm{t}}$, retention time (min); ${ }^{b} \mathrm{Q}$, quality of the library matches $(\%) ;{ }^{c, d}$ relative concentrations of analytes in petrol $(\mathrm{PE})$ and chloroform (CHE) extracts according to peak area ratio (\%) observed in the total ion chromatograms; ${ }^{\mathrm{e}}$ identified with the isolated compounds; ${ }^{\mathrm{f}}$ identified with the corresponding standards; ${ }^{\mathrm{g}}$ identified based on the W9N08.L and NIST 05.L library databases and available literature.

The GC-MS analysis of PE revealed the presence of over sixty constituents, thirty-two of which, representing $86.36 \%$ of the analyzed extract, were identified by comparing their retention times and MS profiles with those of reference standards as well as with literature data and library databases. According to the spectroscopic profiles, four major groups could be distinguished among analytes, including aliphatic hydrocarbons $(8,12,13,15,17,20,22,24,27,34)$, alcohols $(10,16,23,28,29)$, and carboxylic acids $(5,9,11,14,19,33)$, as well as terpenoids (35-40). The dominant group were waxy substances $(47.72 \%$ of the total peak area observed in the extract) represented by simple aliphatic hydrocarbons, among which docosane $(27 ; 18.86 \%)$ and octacosane $(22 ; 11.72 \%)$ were present at the highest percentage, as well as by aliphatic alcohols and carboxylic acids. Waxy alcohols $(1.39 \%)$ and fatty acids (2.34\%) occurred in small amounts, and only $n$-hexadecanoic acid (palmitic acid; 9 ) exceeded the threshold of one percent $(1.42 \%)$. Terpenoids and simple phenols, which also constituted 
a significant proportion of the extract, were represented by methyl benzoate $(3 ; 21.59 \%)$, ursolic acid $(40 ; 4.27 \%)$, $\alpha$-amyrin $(38 ; 3.86 \%), \beta$-sitosterol $(36 ; 2.68 \%)$, oleanolic acid $(39 ; 1.70 \%)$ and methyl salicylate $(\mathbf{1} ; 2.31 \%)$.

Some waxy substances and terpenoic derivatives listed above were also identified in CHE. The GC-MS analysis of this extract revealed the presence of thirty two lipophilic constituents, among which fourteen, representing $81.97 \%$ of the extract, were fully identified. Comparing to PE, the group of simple aliphatic hydrocarbons $(8,21,25 ; 6.40 \%)$, alcohols $(4 ; 2.78 \%)$, and carboxylic acids $(6,9$; $5.79 \%$ ) occurred in CHE at lower levels, and the primary constituents were ursolic acid (40;28.82\%), oleanolic acid $(39 ; 10.11 \%)$, methyl benzoate $(3 ; 10.03 \%)$, and methyl salicylate $(\mathbf{1} ; 6.88 \%)$.

This study is the first to explore chemical composition of petroleum ether and chloroform extracts of G. procumbens leaves. Although the literature for other Gaultheria species concerning the lipophilic components is fragmentary, it is generally in accordance with our findings. For instance, the aliphatic alkanes, i.e., pentadecane, hexadecane, heptadecane, octadecane, nonadecane, eicosane, heneicosane, docosane, and tricosane, were identified by GC-MS as constituents of waxy layers on the G. subcorymbosa and G. antipoda leaf surface [14]. An aliphatic long chain alkane (n-dotriacontane) was identified in aerial parts [12], and palmitic acid in roots [1] of G. yunnanensis. Reports have also indicated the presence of squalene [13], octadecanol, and palmitic acid [1] in the whole plant of G. nummularioides, and palmitic and stearic acids in the whole plant of G. itoana [9]. Similarly, ursolic and oleanolic acids, commonly occurring in the Ericaceae family and identified in this study as the major components of the lipophilic leaf extracts of G. procumbens, were observed earlier in the leaves of G. adenothrix, G. fragrantissima, and G. subcorymbosa [1], roots of G. yunnanensis [1], and the whole plant of G. nummularioides [13] and G. yunnanensis [1,11,12].

The preliminary GC investigations of $\mathrm{CHE}$ revealed the presence of some further components that could not be identified by MS. Three of them occurred in the extract at the levels allowing preparative isolation. The compounds in question gave a purple fluorescence in UV and/or a positive reaction with Liebermann-Burchard reagent indicating phenolic or terpenoic structures. The subsequent preparative open column chromatographic separation followed by flash chromatography afforded pure compounds (Figure 1), NMR data of which are provided in Tables 2 and 3.

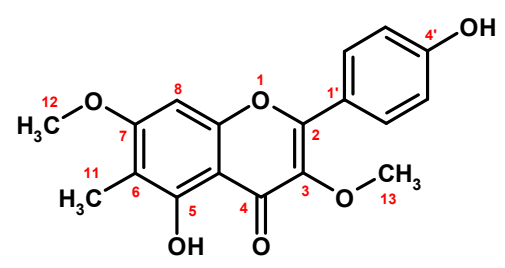

DL

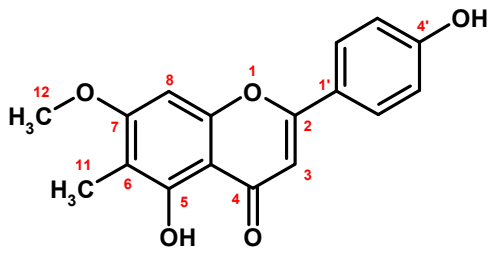

DS

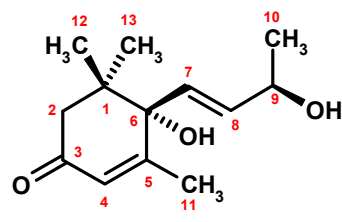

VO

Figure 1. Structures of compounds DL, DS and VO isolated from G. procumbens chloroform extract.

Compounds DL and DS (Figure 1) were isolated as yellow needles. The ESI-MS spectra of both analytes recorded in the negative-ion mode exhibited $[\mathrm{M}-\mathrm{H}]^{-}$ions at $m / z 327$ and 297, respectively, which were consistent with the molecular weights of 328 and 298 , and the molecular formulas $\mathrm{C}_{18} \mathrm{H}_{16} \mathrm{O}_{6}$ and $\mathrm{C}_{17} \mathrm{H}_{14} \mathrm{O}_{5}$, respectively. The UV-Vis spectra of compounds DL and DS with maxima at 270-275 and $330-340 \mathrm{~nm}$ as well as positive results of the Shinoda reaction with the orange color specific to flavone derivatives led to their classification as flavonoids.

The ${ }^{1} \mathrm{H}$ - and ${ }^{13} \mathrm{C}-\mathrm{NMR}$ spectra of $\mathrm{DL}$ in $\mathrm{CDCl}_{3}$ (Table 2 ) revealed the presence of proton and carbon signals typical of a 3,5,6,7, $4^{\prime}$-pentasubstituted flavone [23]. Specifically, signals of five aromatic protons found in the ${ }^{1} \mathrm{H}-\mathrm{NMR}$ at $\delta_{\mathrm{H}} 7.97(2 \mathrm{H}, \mathrm{d}, J=8.7 \mathrm{~Hz}), \delta_{\mathrm{H}} 6.89(2 \mathrm{H}, \mathrm{d}, J=8.7 \mathrm{~Hz})$, and $\delta_{\mathrm{H}} 6.38(1 \mathrm{H}, \mathrm{s})$ indicated a para substitution pattern of the $\mathrm{B}$ ring and the presence of an isolated proton on the A ring. Two three-proton singlets observed at $\delta_{\mathrm{H}} 3.84$ and $\delta_{\mathrm{H}} 3.79$ were assigned to methoxyl groups linked at C-3 and C-7 positions, respectively, according to the HMBC cross 
peaks with carbon resonances at $\delta_{C} 139.1$ and $\delta_{C} 163.5$, characteristic of a 3,7-di-O-substituted flavone. This substitution pattern was further confirmed by UV-Vis analysis with complexation reagents [24]. The third three-proton singlet found in the ${ }^{1} \mathrm{H}-\mathrm{NMR}$ at $\delta_{\mathrm{H}} 2.05$ was attributed to a methyl group at the C-6 position by HMBC cross peaks with the characteristic C-7 and C-5 $\left(\delta_{C} 158.3\right)$ carbon resonances. The substitution position of the single A-ring proton was next assigned to C-8 according to the HMBC correlations with the C-7 and C-9 $\left(\delta_{C}\right.$ 155.0) resonances. The recorded spectral data, consistent with the literature $[25,26]$, led to the identification of compound DL as 4',5-dihydroxy-3,7-dimethoxy-6-methylflavone (8-demethyllatifolin).

Table 2. ${ }^{1} \mathrm{H}-(600 \mathrm{MHz})$ and ${ }^{13} \mathrm{C}-\mathrm{NMR}(151 \mathrm{MHz})$ data for compounds DL and DS.

\begin{tabular}{|c|c|c|c|c|}
\hline \multirow{2}{*}{ Carbon } & \multicolumn{2}{|c|}{ Compound DL $\left(\mathrm{CDCl}_{3}\right)$} & \multicolumn{2}{|c|}{ Compound DS $\left(\mathrm{CDCl}_{3}\right)$} \\
\hline & $\delta_{H}(p p m)^{a}$ & $\delta_{C}(p p m)^{a}$ & $\delta_{H}(p p m)^{a}$ & $\delta_{C}(p p m)^{a}$ \\
\hline 2 & & 155.5 & & 155.7 \\
\hline 3 & & 139.1 & $6.58(1 \mathrm{H}, \mathrm{s})$ & 101.1 \\
\hline 4 & & 178.7 & & 177.9 \\
\hline 5 & & 158.3 & & 157.3 \\
\hline 6 & & 108.7 & & 108.3 \\
\hline 7 & & 163.5 & & 163.1 \\
\hline 8 & $6.38(1 \mathrm{H}, \mathrm{s})$ & 89.1 & $6.42(1 \mathrm{H}, \mathrm{s})$ & 90.2 \\
\hline 9 & & 155.0 & & 154.6 \\
\hline 10 & & 105.9 & & 104.8 \\
\hline $\mathbf{1}^{\prime}$ & & 123.4 & & 122.6 \\
\hline $2^{\prime}, 6^{\prime}$ & $7.97(2 \mathrm{H}, \mathrm{d}, J=8.7 \mathrm{~Hz})$ & 130.4 & $7.74(2 \mathrm{H}, \mathrm{d}, J=8.7 \mathrm{~Hz})$ & 130.2 \\
\hline $3^{\prime}, 5^{\prime}$ & $6.89(2 \mathrm{H}, \mathrm{d}, J=8.7 \mathrm{~Hz})$ & 115.6 & $6.91(2 \mathrm{H}, \mathrm{d}, J=8.7 \mathrm{~Hz})$ & 115.6 \\
\hline $4^{\prime}$ & & 157.8 & & 159.3 \\
\hline 11 & $2.05(3 \mathrm{H}, \mathrm{s})$ & 7.2 & $2.05(3 \mathrm{H}, \mathrm{s})$ & 7.2 \\
\hline 12 & $3.79(3 \mathrm{H}, \mathrm{s})$ & 60.1 & $3.86(3 \mathrm{H}, \mathrm{s})$ & 59.7 \\
\hline 13 & $3.84(3 \mathrm{H}, \mathrm{s})$ & 55.9 & & - \\
\hline
\end{tabular}

The ${ }^{1} \mathrm{H}$ - and ${ }^{13} \mathrm{C}-\mathrm{NMR}$ spectra of $\mathbf{D S}$ in $\mathrm{CDCl}_{3}$ (Table 2) were similar to those of compound DL, with one exception. Specifically, the three-proton signal of the methoxyl group at C-3 position was replaced by a one-proton singlet at $\delta_{\mathrm{H}} 6.58$ correlating with the carbon signal at $\delta_{\mathrm{C}} 101.1$ in the HMQC spectrum, which was, nevertheless, still assigned to C-3 position due to the observed large upfield shift $\left(\Delta \delta_{C}=-38.0\right)$ of the carbon resonance after cleavage of an electronegative (methoxyl) substituent. Eventually, according to the recorded and literature data [26,27] compound DS was identified as 4',5-dihydroxy-7-methoxy-6-methylflavone (8-demethylsideroxylin).

Compound VO (Figure 1) was isolated as white needles. The ESI-MS spectrum recorded in the positive-ion mode exhibited the presence of pseudomolecular $[\mathrm{M}+\mathrm{H}]^{+}$ion at $m / z 225$, which was consistent with the molecular weight of 224 and molecular formula $\mathrm{C}_{13} \mathrm{H}_{20} \mathrm{O}_{3}$. The tested compound gave a positive reaction with Liebermann-Burchard reagent, yielding the yellow color specific to low-molecular terpenoic derivatives. The ${ }^{1} \mathrm{H}-\mathrm{NMR}$ spectrum of $\mathrm{VO}$ in $\mathrm{CDCl}_{3}$ (Table 3) showed the presence of proton signals characteristic of a substituted $\alpha$-ionol [28], i.e., three olefinic proton signals at $\delta_{\mathrm{H}} 5.90(1 \mathrm{H}, \mathrm{br} \mathrm{s}), 5.85\left(1 \mathrm{H}, \mathrm{dd}, J_{1}=5.3 \mathrm{~Hz}, J_{2}=15.8 \mathrm{~Hz}\right)$, and $5.79\left(1 \mathrm{H}, \mathrm{dd}, J_{1}=0.8 \mathrm{~Hz}\right.$, $\left.J_{2}=15.8 \mathrm{~Hz}\right)$, as well as four resonances of methyl groups, including two doublets at $\delta_{\mathrm{H}} 1.89(3 \mathrm{H}, \mathrm{d}$, $J=1.1 \mathrm{~Hz})$ and $1.30(3 \mathrm{H}, \mathrm{d}, J=6.4 \mathrm{~Hz})$, and two singlets at $\delta_{\mathrm{H}} 1.08$ and 1.01. Out of the five remaining proton signals typical of $\alpha$-ionol, only two resonances, with the geminal coupling constant at $\delta_{\mathrm{H}}$ $2.44 \mathrm{ppm}(1 \mathrm{H}, \mathrm{d}, J=16.9 \mathrm{~Hz})$ and $2.24 \mathrm{ppm}(1 \mathrm{H}, \mathrm{d}, J=16.9 \mathrm{~Hz})$, were present, indicating substitution at the cyclohexane ring. In the IR spectrum of VO signals of the carbonyl $(\mathrm{C}=\mathrm{O})$ and hydroxyl groups $(\mathrm{OH})$ were visible at $1659 \mathrm{~cm}^{-1}$ and $3355 \mathrm{~cm}^{-1}$, respectively. The position of the carbonyl group was assigned to $\mathrm{C}-3$ based on the HMBC cross peak between the olefinic proton signal at $\mathrm{C}-4$ $\left(\delta_{\mathrm{H}} 5.90,1 \mathrm{H}, \mathrm{br} \mathrm{s}\right)$ and the carbonyl resonance $\left(\delta_{\mathrm{C}} 197.9\right)$. The position of the hydroxyl group at $\mathrm{C}-6$ 
was next determined according to the large downfield shift $\left(\Delta \delta_{C}=+24.7\right)$ for $C-6$ carbon signal in comparison with the predicted corresponding signal of $\alpha$-ionol [28]. The postulated chemical structure was confirmed by ${ }^{13} \mathrm{C}-\mathrm{NMR}$ and $2 \mathrm{D}$ NMR $\left({ }^{1} \mathrm{H}-{ }^{1} \mathrm{H}\right.$ COSY, HMQC, HMBC) experiments. The absolute configuration of the chiral centers in the compound VO was determined by measuring the optical rotation $[\alpha]_{\mathrm{D}}^{20}=+211.5^{\circ}\left(c=1.06 \mathrm{~g} / 100 \mathrm{~mL}, \mathrm{CHCl}_{3}\right)$, that stands in accordance with the literature data for the $(6 S, 9 R)$ isomer [29]. Finally, the compound VO was identified as $(6 S, 9 R)$-vomifoliol, that is $(6 S, 9 R)-6$-hydroxy-3-oxo- $\alpha$-ionol.

Table 3. ${ }^{1} \mathrm{H}-(600 \mathrm{MHz})$ and ${ }^{13} \mathrm{C}-\mathrm{NMR}(151 \mathrm{MHz})$ data for compound VO.

\begin{tabular}{ccc}
\hline \multirow{2}{*}{ Carbon } & \multicolumn{2}{c}{ Compound VO $\left(\mathbf{C D C l}_{\mathbf{3}}\right)$} \\
\cline { 2 - 3 } & $\boldsymbol{\delta}_{\mathbf{H}}(\mathbf{p p m})^{\mathbf{a}}$ & $\boldsymbol{\delta}_{\mathbf{C}}(\mathbf{p p m})^{\mathbf{a}}$ \\
\hline $\mathbf{1}$ & $2.24(1 \mathrm{H}, \mathrm{d}, J=16.9 \mathrm{~Hz})$ & 41.2 \\
$\mathbf{2 a}$ & $2.44(1 \mathrm{H}, \mathrm{d}, J=16.9 \mathrm{~Hz})$ & 49.7 \\
$\mathbf{2} \mathbf{b}$ & & 197.9 \\
$\mathbf{3}$ & $5.90(1 \mathrm{H}, \mathrm{br} \mathrm{s})$ & 126.9 \\
$\mathbf{4}$ & & 162.6 \\
$\mathbf{5}$ & & 79.1 \\
$\mathbf{6}$ & & 129.0 \\
$\mathbf{7}$ & $5.79\left(1 \mathrm{H}, \mathrm{dd}, J_{1}=0.8 \mathrm{~Hz}, J_{2}=15.8 \mathrm{~Hz}\right)$ & 135.8 \\
$\mathbf{8}$ & $5.85\left(1 \mathrm{H}, \mathrm{dd}, J_{1}=5.3 \mathrm{~Hz}, J_{2}=15.8 \mathrm{~Hz}\right)$ & 68.0 \\
$\mathbf{9}$ & $4.40\left(1 \mathrm{H}, \mathrm{dq}, J_{1}=5.3 \mathrm{~Hz}, J_{2}=6.4 \mathrm{~Hz}\right)$ & 23.8 \\
$\mathbf{1 0}$ & $1.30(3 \mathrm{H}, \mathrm{d}, J=6.4 \mathrm{~Hz})$ & 18.9 \\
$\mathbf{1 1}$ & $1.89(3 \mathrm{H}, \mathrm{d}, J=1.1 \mathrm{~Hz})$ & 22.9 \\
$\mathbf{1 2}$ & $1.01(3 \mathrm{H}, \mathrm{s})$ & 24.1 \\
$\mathbf{1 3}$ & $1.08(3 \mathrm{H}, \mathrm{s})$ & \\
\hline
\end{tabular}

${ }^{\mathrm{a}}$ assignments confirmed by ${ }^{1} \mathrm{H}-{ }^{1} \mathrm{H}$ COSY, $\mathrm{HMQC}$, and $\mathrm{HMBC}$ experiments.

This work is the first report on the presence of $(6 S, 9 R)$-vomifoliol (VO) in the leaves of G. procumbens and in the whole genus Gaultheria. Vomifoliol occurs commonly in the plant kingdom, but was earlier identified in Ericaceae family only by GC-MS as the component of the aroma fraction isolated from Arbutus unedo honey [30]. Two rare lipophilic flavonoid aglycones, i.e., 8-demethyllatifolin (DL) and 8-demethylosideroxylin (DS), were reported previously as components of the lipophilic wax layer on the G. procumbens leaf surface but with structure analysis based only on UV-Vis spectroscopy and lacking NMR data [26]. Apart from G. procumbens, compound DL was also identified in a few representatives of Pinaceae and Myrtaceae, and DS in those of Ranunculaceae, Hypericaceae, and Myrtaceae [25,27,31].

\subsection{Activity of G. procumbens Dry Lipophilic Leaf Extracts on Two Enzymes Involved in Inflammation}

Inflammation is a part of the complex biological response of body tissues to harmful stimuli, such as pathogens or irritants. During the process, different cell types like macrophages and monocytes are recruited, what leads to the regulated production of various pro- and anti-inflammatory mediators, including cytokines, chemokines, and inducible enzymes [32]. Among many methods used for activity screening of anti-inflammatory agents, one of the most commonly employed techniques is based upon the ability of natural compounds to inhibit the pro-inflammatory enzymes, which include i.a. lipoxygenases and hyaluronidase.

Therefore, the inhibitory effects of lipophilic extracts of the wintergreen leaves and their pure constituents representing all metabolite groups found by GC-MS towards enzymes from both aforementioned pro-inflammatory classes were measured in this study.

As presented in Figure 2, the strongest inhibitory potential towards hyaluronidase was demonstrated by CHE $\left(\mathrm{IC}_{50}=282.15 \pm 10.38 \mu \mathrm{g} / \mathrm{mL}\right)$, which exhibited 1.3 times higher inhibitory activity than positive heparin control $\left(\mathrm{IC}_{50}=366.24 \pm 14.72 \mu \mathrm{g} / \mathrm{mL}\right)$ and 1.4 times stronger capacity than PE $\left(\mathrm{IC}_{50}=401.82 \pm 16.12 \mu \mathrm{g} / \mathrm{mL}\right)$. The anti-hyaluronidase activity of $\mathbf{C H E}$ and $\mathbf{P E}$ was comparable or even higher than that of the most active terpenoid and flavonoid components of the extracts, such as 
UA, OA, DS, DL and VO. The activity of SM, BM and $\beta$-SIT was, in turn, much weaker-2.4-2.8 times lower than that of CHE, and 1.7-2.0 times lower than that of PE. At the same conditions, DOC presented no inhibitory activity towards hyaluronidase in the tested concentration range. Comparison of the activity parameters and GC peak areas observed for all analytes indicated, on one hand, significant synergistic effects of components of both extracts, and the dominant impact of UA and OA on the anti-inflammatory activity of CHE (according to their high abundance of $28.82 \%$ and $10.11 \%$ of the extract, respectively) on the other.

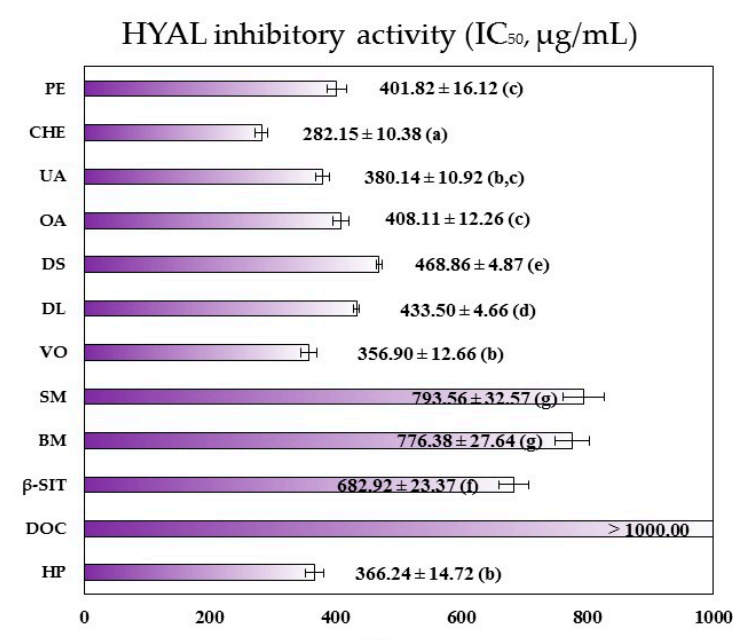

(a)

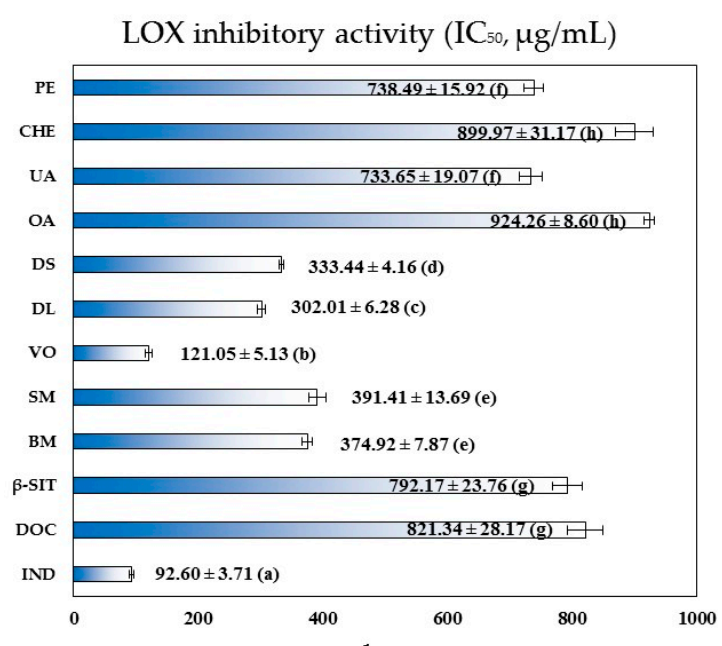

(b)

Figure 2. Anti-inflammatory activity of G. procumbens dry lipophilic leaf extracts; inhibitory activity on: (a) hyaluronidase and (b) lipoxygenase. Results are presented as mean values \pm SD $(n=3 \times 2)$ represented by error bars; $\mathrm{IC}_{50}, 50 \%$ inhibition of enzyme activity; for each parameter different lowercase letters given in parentheses $(\mathrm{a}-\mathrm{h})$ indicate significant differences between the mean values $(p<0.05)$ in the Tukey's test; abbreviations: PE, petroleum ether extract; CHE; chloroform extract; UA, ursolic acid; OA, oleanolic acid; DS, 8-demethylsideroxylin; DL, 8-demethyllatifolin; VO, $(6 S, 9 R)$-vomifoliol; SM, methyl salicylate; BM, methyl benzoate; $\beta$-SIT, $\beta$-sitosterol; DOC, docosane; positive standards: IND, indomethacin; HP, heparin.

The analyzed lipophilic extracts and their constituents were in general less effective inhibitors of lipoxygenase than hyaluronidase (Figure 2). Among the extracts, higher inhibitory activity towards lipoxygenase was this time observed for PE $\left(\mathrm{IC}_{50}=738.49 \pm 15.92 \mu \mathrm{g} / \mathrm{mL}\right)$, which was, nevertheless, 8 times lower than the activity of positive indomethacin control $\left(\mathrm{IC}_{50}=92.60 \pm 3.71 \mu \mathrm{g} / \mathrm{mL}\right.$ ). The inhibitory potential of CHE $\left(\mathrm{IC}_{50}=899.97 \pm 31.17 \mu \mathrm{g} / \mathrm{mL}\right)$ was, in turn, about 9.7-fold lower than in the case of indomethacin. The anti-lipoxygenase activity of CHE and PE was comparable to that of UA, OA, $\beta$-SIT and DOC. Other components of the extracts, i.e., DS, DL, SM and BM, were 2.3-3.0 times stronger inhibitors of lipoxygenase than CHE, and 1.9-2.4 times more effective than PE, but still noticeably less active (3-4 times weaker) than the positive control. Only the low-molecular terpenoic derivative $(\mathrm{VO})$ presented activity $\left(\mathrm{IC}_{50}=121.97 \pm 5.13 \mu \mathrm{g} / \mathrm{mL}\right)$ comparable to that of indomethacin, which suggested possible significant impact of $\mathbf{V O}$ on the anti-inflammatory activity of the wintergreen leaves. On the other hand, VO was present just in the less active extract (CHE), and only at the low concentration of $4.35 \%$. Similar observations can be made for three further most active analytes, i.e., SM, and both flavonoids (DL and DS), which were absent from the more effective extract (PE) or found only at low levels. Therefore none of the tested in the present study components could be indicated as solely responsible for the anti-lipoxygenase activity of the extracts, as it corresponded rather to additive and/or synergistic effects of all analytes. Nevertheless, the relatively high contents of BM $(21.59 \%)$ and DOC (18.86\%) in PE, and UA (28.82\%), OA $(10.11 \%)$, and BM $(10.03 \%)$ in CHE may indicate their considerable relevance to the inhibitory activity towards lipoxygenase. 
To the best of our knowledge, this work is the first to compare in one study design the hyaluronidase and lipoxygenase inhibitory activity of natural lipophilic compounds representing various chemical groups, such as salicylates, phytosterols, triterpene acids, $\mathrm{C}_{13}$-norisoprenoids, aliphatic alkanes, and methoxylated flavonoids, and therefore provides better insight into the nature and extent of the activity of lipophilic plant extracts. The work is also the first to provide the target activity parameters for DS, DL, VO and DOC.

As indicated above, the anti-inflammatory activity of the analyzed extracts was due to additive and/or synergistic effects of their numerous components. However, as especially high inhibitory effect was observed towards hyaluronidase, the major determinants of this activity, i.e., UA and OA, should be recommended as analytical markers for standardization of the G. procumbens extracts and raw leaf material.

Triterpene compounds, represented in the wintergreen extracts mainly by $\mathbf{U A}$ and $\mathbf{O A}$, are widely distributed in the plant kingdom and characterized by a vast range of pharmacological activities $[17,33]$. Triterpene acids exhibit the ability to reduce inflammation in various mechanisms, e.g., by inhibition of enzymes involved in the inflammatory response. Apart from hyaluronidase and lipoxygenase analyzed in the present study, they may also influence phospholipase A2, cyclooxygenase (COX), nitric oxide synthase, and elastase [34]. Moreover, the acids can reduce the formation of pro-inflammatory mediators, such as prostaglandins and cytokines [35]. The ability of UA to attenuate expression of COX-2 and the secretion of pro-inflammatory cytokines, like tumor necrosis factor (TNF- $\alpha$ ), interferon $\gamma($ IFN- $\gamma$ ) and interleukins (e.g., IL-6), is also associated with its anticancer activity since chronic inflammation is recognized as a cancerogenesis-promoting condition [36]. The activity profile of the aforementioned triterpene acids suggests that for $\mathrm{CHE}$, proven in the present work to be a good source of UA $(28.82 \%)$ and OA $(10.11 \%)$, a wide range of possible applications as an anti-inflammatory agent could be expected.

The dominant components of PE were aromatic esters-BM (21.59\%) and SM (2.31\%)—and waxy substances represented mainly by DOC $(18.86 \%)$ and octacosane $(11.72 \%)$. While natural salicylates have well documented anti-inflammatory activity [4-6], the potential of waxy substances is described only indirectly by activity profiling of wax-rich plants. According to the literature, significant amounts of simple aliphatic hydrocarbons, fatty alcohols ( $n$-docosanol, $n$-octacosanol), saturated (lauric and palmitic acids) and unsaturated fatty acids (oleic, linoleic and linolenic acids), which are common components of waxy layers coating aerial organs of plants, are present in lipophilic extracts of some valuable herbal materials, such as Prunus africana bark, Serenoa repens fruits, and Cucurbita pepo seeds [37-41]. The waxy constituents of these plant materials are co-responsible, together with the fraction of phytosterols, for alleviating the inflammation-related symptoms of some urinary disorders such as benign prostatic hyperplasia via modulation of pro-inflammatory genes, inhibition of COX synthesis, and alteration in NF-KB signal transduction pathways [42]. Free fatty acids can act as anti-inflammatory agents also by reducing activation of leukocytes and decreasing the production of reactive oxygen species and pro-inflammatory mediators, like IL-1 $\beta$ and TNF- $\alpha[43,44]$. Taking into account the biological activity of waxy substances, the existing literature indicates potentially broad application of wintergreen PE, especially rich in this group of components. The G. procumbens extract is also characterized by high extraction yield $(12.2 \%)$, and thus it could be considered as an interesting alternative to the commercially available products.

\subsection{Seasonal Variation in the Content of Triterpene Acids in G. procumbens Leaves}

The triterpene acids $\mathbf{U A}$ and $\mathbf{O A}$, recommended as analytical markers of anti-inflammatory active wintergreen lipophilic extracts, were simultaneously determined by UHPLC-PDA in the leaf samples of G. procumbens harvested monthly across the full growing season. The validated assay protocol, optimized to assure the best recovery of both analytes from plant materials, was previously developed in our laboratory [45] for standardization of Ericaceae herbal medicines. 
In all of the tested plant samples, OA and UA constituted the dominating part of the triterpene acid fraction, with other triterpene peaks negligible or not existing at the detection wavelength of $215 \mathrm{~nm}$ (Figure S3). The content of UA and OA in the investigated plant samples varied from $3.71 \pm 0.07$ to $5.87 \pm 0.21 \mathrm{mg} / \mathrm{g}$ DW and $0.84 \pm 0.01$ to $1.26 \pm 0.03 \mathrm{mg} / \mathrm{g}$ DW of the plant material, respectively (Figure 3). With the levels generally 4.5 times higher than those of OA, and reaching approximately $81.5 \%-83.1 \%$ of the total triterpene acid content, the primary constituent in all samples was UA. The highest concentrations of UA (5.67-5.87 mg/g DW) were found for two autumn months (September-October) followed by the months of late summer (July-August; 5.36-5.41 mg/g DW). In spring and early summer (April-June) the UA levels were significantly lower $(p<0.05)$ and the differences were up to $37 \%$ of the highest October concentration. The variations in OA levels were less pronounced (0.84-1.26 mg/g DW), and the peak contents were observed in July and October (1.20-1.26 mg/g DW). However, in early spring (April), late summer (August), and early autumn (September), the tested leaves accumulated only slightly lower OA levels (1.11-1.15 mg/g DW). That means that high amounts of the triterpene acids were biosynthesized in a relatively long vegetation period, i.e., between August and October (6.50-7.07 mg/g DW), indicating potentially good elasticity when selecting the harvest time. As similar seasonal dynamics was found earlier for polar anti-inflammatory constituents of G. procumbens leaves [21], the plant could be considered attractive for industrial purposes and affording both high quality lipophilic and polar extracts at the same, relatively wide vegetation period.

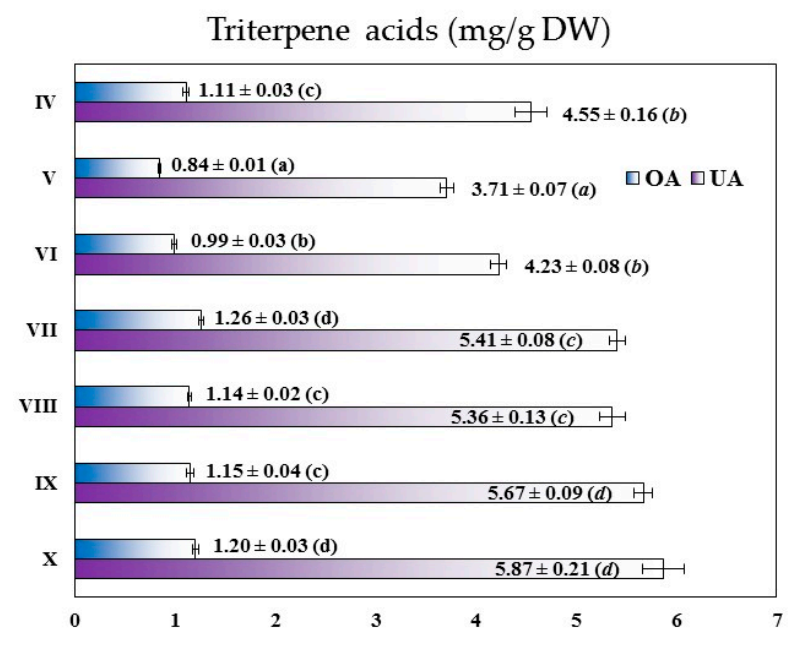

Figure 3. Seasonal variation (IV-X 2014) in the content of oleanolic and ursolic acid in the leaves of G. procumbens. Results are presented as mean values calculated per dry weight of the plant material \pm $\mathrm{SD}(n=3 \times 3)$ represented by error bars, different superscripts $(\mathrm{a}-\mathrm{d})$ indicate significant differences in the mean values at $p<0.05$ by the Tukey's test; abbreviations: OA, oleanolic acid; UA, ursolic acid.

Free triterpene acids UA and OA occur commonly in different species of the Ericaceae family. One of the plant materials richest in these compounds are bearberry leaves (Arctostaphylos uva-ursi), which may contain up to $15 \mathrm{mg} / \mathrm{g}$ DW of the sum of triterpene acids, including $12.4 \mathrm{mg} / \mathrm{g}$ DW of UA and $2.7 \mathrm{mg} / \mathrm{g}$ DW of OA [46]. The triterpene acids content in other Ericaceae plants is generally lower. For instance, the leaves of lingonberry (Vaccinium vitis-idaea) contained $2.50-6.76 \mathrm{mg} / \mathrm{g}$ DW of UA and $0.74-2.15 \mathrm{mg} / \mathrm{g}$ DW of OA $[45,47,48]$, while the content of both acids in the bilberry leaves (Vaccinium myrtillus) varied in the range of $0.75-1.30 \mathrm{mg} / \mathrm{g}$ DW for UA and $0.28-1.78 \mathrm{mg} / \mathrm{g} \mathrm{DW}$ for OA $[45,49,50]$. Similarly, the sum of UA and OA in the leaves of Rhododendron adamsii reached $3.1 \mathrm{mg} / \mathrm{g}$ DW [51]. Taking into account the literature, the UA and OA levels observed in the present study put G. procumbens in a very good position comparing to other Ericaceae members, and the analyzed leaves could be thus considered good source of the isomeric triterpene acids. 


\section{Materials and Methods}

\subsection{General Information}

HPLC grade reagents and standards, such as bovine testis hyaluronidase; bovine serum albumin; hyaluronic acid; lipoxygenase from soybean; $\mathrm{N}, \mathrm{O}$-bis-(trimethylsilyl)-trifluoroacetamide with 1-trimethylchlorosilane (BSTFA + TMCS); indomethacin; linoleic acid; ursolic acid; oleanolic acid; $\beta$-sitosterol; methyl benzoate; methyl salicylate; and docosane were purchased from Sigma-Aldrich (Seelze, Germany/St. Louis, MO, USA). Heparin sodium salt was purchased from WZF Polfa (Warsaw, Poland). HPLC grade solvents (methanol and orthophosphoric acid) were from Avantor Performance Materials (Avantor PM, Gliwice, Poland). All other chemicals and solvents were of analytical grade and supplied by Avantor PM. In all analyses redistilled water was used. Enzymatic tests were done using 96-well plates and monitored using a Synergy 4 microplate reader (BioTek, Winooski, VT, USA). Column chromatography (CC) was performed on silica gel 60 G (0.2-0.5 mm, Macherey-Nagel, Düren, Germany). Analytical TLC was carried out on silica gel $60 \mathrm{G}$ precoated plates (Merck, Warsaw, Poland) using horizontal DC chambers (Chromdes, Lublin, Poland). Flash chromatography was carried out on an Interchim puriFlash ${ }^{\mathrm{TM}} 430$ evo chromatograph (Interchim Inc., San Pedro, CA, USA) equipped with a UV-Vis detector scanning in the wavelength range of 200-600 nm, a fraction collector, and Interchim puriFlash Silica HC ( $50 \mu \mathrm{m}, 72 \mathrm{~mm} \times 15 \mathrm{~mm}, 4 \mathrm{~g})$ preparative columns. The flow rate was $7 \mathrm{~mL} / \mathrm{min}$. The mobile phase consisted of petroleum ether (A), chloroform (B), and methanol (C). A linear gradient system was used for elution (A:B:C): 0-9 min, 75:25:0 (v/v/v); 9-10 min, 49:49:2; 10-15 min, 45:45:10. Before injection, samples were dissolved in chloroform. Melting points (uncorrected) were determined on a Boetius apparatus (Carl Zeiss, Jena, Germany). UV-Vis spectra, before and after adding ionization and complexation reagents, were recorded at $25^{\circ} \mathrm{C}$ on a UV-1601 Spectrophotometer (Rayleigh, Beijing, China) in methanol, according to Mabry et al. [24]. ESI-MS spectra were measured on a UHPLC-3000 RS chromatograph (Dionex, Dreieich, Germany) equipped with a dual low-pressure gradient pump, an autosampler, a diode array detector, and an AmaZon SL ion trap mass spectrometer with an ESI interface (Bruker Daltonik, Bremen, Germany). IR spectra were recorded in KBr on a Bruker Alpha FT-IR spectrometer (Bruker Daltonik). Optical rotation $\left([\alpha]_{\mathrm{D}}^{20}\right)$ was measured in chloroform on a PolAAr 3001 polarimeter (Optical Activity, Ramsey, UK). ${ }^{1} \mathrm{H}-\mathrm{NMR},{ }^{13} \mathrm{C}-\mathrm{NMR},{ }^{1} \mathrm{H}-{ }^{1} \mathrm{H}$ COSY, HMQC, and $\mathrm{HMBC}$ spectra were recorded at $25^{\circ} \mathrm{C}$ on a Bruker Daltonik III $600 \mathrm{MHz}$ spectrometer in $\mathrm{CDCl}_{3}$ and with TMS as the internal standard.

\subsection{Plant Material and Preparation of Plant Extracts}

\subsubsection{Plant Material}

Leaves of Gaultheria procumbens L. were collected in October 2014 (for preparative extraction, isolation, GC-MS analysis, and activity studies), as well as monthly between April and October 2014 (for analysis of the seasonal variation of triterpene acids) in the nursery-garden of Ericaceae plants, Gospodarstwo Szkolkarskie Jan Cieplucha ( $\left.54^{\circ} 44^{\prime} \mathrm{N}, 19^{\circ} 18^{\prime} \mathrm{E}\right)$, Konstantynow Lodzki, Poland, where the plants grew in an open area. The seeds for the nursery were imported from the William J. Beal Botanical Garden (Michigan State University, East Lansing, MI, USA), and authenticated by Piotr Banaszczak, Head of the Arboretum, Forestry Experimental Station of Warsaw University of Life Sciences (SGGW) in Rogow, Poland. The voucher specimen was deposited in the herbarium of the Department of Pharmacognosy, Medical University of Lodz, Poland, with the number KFG/HB/14001-GPRO. Leaf samples for the analysis of seasonal variation were collected each time from ten random plants selected from healthy individuals separated by minimum $5 \mathrm{~m}$ and representing the average development stage at the sampling site. Samples of the plant material were air-dried under normal conditions, powdered with an electric grinder, and sieved through a ø 0.315-mm sieve. 


\subsubsection{Preparation of Dry Lipophilic Leaf Extracts}

The preparative sample $(1000 \mathrm{~g})$ of the pulverized plant material was extracted in a Soxhlet apparatus first with petroleum ether $(1 \mathrm{~L}, 72 \mathrm{~h})$ and then with chloroform $(1 \mathrm{~L}, 72 \mathrm{~h})$. The obtained fractions were concentrated in vacuo to yield petroleum ether (PE, $122.0 \mathrm{~g}, 12.2 \% \mathrm{DW})$ and chloroform (CHE, $74.0 \mathrm{~g}, 7.4 \% \mathrm{DW}$ ) dry extracts. The extraction yield was defined as the amount of the dried extract obtained from $100 \mathrm{~g}$ of the dried plant material.

\subsubsection{Preparation of Plant Extracts for UHPLC-PDA Quantification of Triterpene Acids}

The accurately weighed samples of the pulverized plant material $(300 \mathrm{mg})$ were sequentially refluxed twice for $30 \mathrm{~min}$ with $30 \mathrm{~mL}$ of chloroform, and finally once for 30 min with $30 \mathrm{~mL}$ of chloroform-methanol $(1: 1, v / v)$. The combined extracts were evaporated to dryness in vacuo. The residue was dissolved in $4 \mathrm{~mL}$ of chloroform-methanol $(1: 1, v / v)$, diluted with methanol to $10 \mathrm{~mL}$, filtered through a PTFE syringe filter $(25 \mathrm{~mm}, 0.2 \mu \mathrm{m}$, Vitrum, Prague, Czech Republic) and directly analyzed by UHPLC-PDA (Section 3.3.3). The determinations were performed after three separate extractions of each sample.

\subsection{Phytochemical Profiling}

\subsubsection{Qualitative GC-MS Analysis of G. procumbens Dry Leaf Extracts}

The analysis was performed on an Agilent 6890N Network Gas Chromatograph combined with an Agilent 5973 Mass Selective Detector and equipped with a silica fused capillary column DB-5MS ( $30 \mathrm{~m} \times 0.25 \mathrm{~mm}$ i.d., film thickness $0.25 \mu \mathrm{m}$; Agilent Technologies, Santa Clara, CA, USA). The oven temperature was programmed from $80{ }^{\circ} \mathrm{C}$ to $270{ }^{\circ} \mathrm{C}$ at a rate of $10{ }^{\circ} \mathrm{C} / \mathrm{min}$. The flow rate of the carrier gas (helium) was $0.6 \mathrm{~mL} / \mathrm{min}$. The injector and the interface (between GC and MS) were kept at $250{ }^{\circ} \mathrm{C}$. The samples of the dry extracts (PE and CHE, $\left.10 \mathrm{mg} / \mathrm{mL}\right)$ and standards $(1 \mathrm{mg} / \mathrm{mL}$ ) were dissolved in toluene and derivatized with BSTFA+TMCS $(100 \mu \mathrm{L})$ for $3 \mathrm{~h}$ in the dark. After this time the samples were injected $(1 \mu \mathrm{L})$ into the GC-MS system. Identification of the compounds was performed on the basis of their chromatographic behavior (retention times) and MS-spectra in comparison with the standards (both retention times and MS-data) and W9N08.L and NIST 05.L library databases (MS-fragmentation). In all cases when the standards were unavailable, the quality of the library matches ranged from $90 \%$ to $99 \%$.

\subsubsection{Isolation and Structure Elucidation}

The preparative CHE sample (70 g) was dissolved in boiling methanol $(500 \mathrm{~mL})$. After cooling, the precipitated waxes were removed by filtration. The filtrate was evaporated to dryness in vacuo and then re-dissolved in chloroform $(50 \mathrm{~mL})$. The purified extract was separated by column chromatography on silica gel using benzene-ethyl acetate with ethyl acetate gradient as an eluent. The TLC chromatograms (silica gel; benzene-chloroform-methanol, 20:30:4, $v / v / v$ ) were analyzed in UV light at $365 \mathrm{~nm}$, before and after detection at $110{ }^{\circ} \mathrm{C}$ with a Liebermann-Burchard reagent (ethanol-acetic anhydride- $96 \%$ sulphuric acid, 10:1:1, $v / v / v)$. Based on the chromatographic profile three fractions were selected: T1 (459 mg; eluted with benzene-ethyl acetate, 90:10, $v / v)$, T2 (1.321 g; benzene-ethyl acetate, 85:15, $v / v$ ) and T3 (458 mg; benzene-ethyl acetate, 50:50, $/ / v)$. After evaporating the solvents, the fractions T1, T2 and T3 were re-dissolved in small amounts of chloroform and separated independently by flash chromatography (Section 3.1) to give three pure compounds: DL (55 mg), DS (57 mg) and VO (82 $\mathrm{mg})$, respectively.

Compound DL (yellow needles), m.p. $215-220{ }^{\circ} \mathrm{C}$, positive reaction (orange color) in the Shinoda test. $\mathrm{UV}(\mathrm{MeOH}) \lambda_{\max } \mathrm{nm}: 271,340 ; \mathrm{NaOMe} 255,269 ; \mathrm{AlCl}_{3}$ 272, 299 (sh), 349; $\mathrm{AlCl}_{3}-\mathrm{HCl}$ 275, 307 (sh), 356; $\mathrm{NaOAc} 271,375 ; \mathrm{NaOAc}-\mathrm{H}_{3} \mathrm{BO}_{3}$ 271, 340. ESI-MS: $m / z$ [M - H] $327(100 \%), \mathrm{MS}^{2}$ : [M - H - $\left.\mathrm{CH}_{3}\right]^{-}$ $312(91.3 \%) .{ }^{1} \mathrm{H}$ - and ${ }^{13} \mathrm{C}-\mathrm{NMR}$ data are presented in Table 2. 
Compound DS (yellow needles), m.p. $285-290^{\circ} \mathrm{C}$, positive reaction (orange color) in the Shinoda test. UV (MeOH) $\lambda_{\max }$ nm: 274, 331; NaOMe 259 (sh), 271, 385; $\mathrm{AlCl}_{3} 292$ (sh), 300, 354; $\mathrm{AlCl}_{3}-\mathrm{HCl} 289$ (sh), 300, 353; NaOAc 272, 385; NaOAc- $\mathrm{H}_{3} \mathrm{BO}_{3}$ 273, 335. ESI-MS: $m / z$ [M - H] $]^{-} 297$ (100\%), $\mathrm{MS}^{2}:[\mathrm{M}-\mathrm{H}$ $\left.-\mathrm{CH}_{3}\right]^{-} 282(84.5 \%) .{ }^{1} \mathrm{H}$ and ${ }^{13} \mathrm{C}-\mathrm{NMR}$ data are presented in Table 2.

Compound VO (white needles), m.p. $105-108^{\circ} \mathrm{C}$, positive reaction (yellow color) with LiebermannBurchard reagent. $[\alpha]_{\mathrm{D}}^{20}=+211.5^{\circ}\left(c=1.06 \mathrm{~g} / 100 \mathrm{~mL}, \mathrm{CHCl}_{3}\right)$. UV $(\mathrm{MeOH}) \lambda_{\max } \mathrm{nm}: 236 . \mathrm{IR} v_{\max } \mathrm{KBr}$ $\mathrm{cm}^{-1}: 3355(\mathrm{OH}), 2864,1659(\mathrm{C}=\mathrm{O}), 1431,1387,1277,1019$, 970. ESI-MS: $m / z[2 \mathrm{M}+\mathrm{H}]^{+} 449(100 \%)$, $\mathrm{MS}^{2}:[\mathrm{M}+\mathrm{H}]^{+} 225(20.7 \%),\left[\mathrm{M}+\mathrm{H}-\mathrm{CH}_{3}\right]^{+} 207(100 \%),\left[\mathrm{M}+\mathrm{H}-2 \mathrm{CH}_{3}\right]^{+} 189(13.8 \%) .{ }^{1} \mathrm{H}-$ and ${ }^{13} \mathrm{C}-\mathrm{NMR}$ data are presented in Table 3.

\subsubsection{Quantitative UHPLC-PDA Analysis of Triterpene Acids in G. procumbens Leaves}

UHPLC-PDA analyses were carried out on an Agilent Technologies 1290 Infinity chromatograph (Agilent Technologies) according to the method of Owczarek et al. [45]. The system was equipped with a photodiode array detector (PDA), thermostat, and autosampler. Separations were carried out on a Zorbax Eclipse XDB-C18 column (1.8 $\mu \mathrm{m}, 100 \mathrm{~mm} \times 3.0 \mathrm{~mm}$ I.D.; Agilent Technologies). The mixture 90:10 $(v / v)$ of methanol and $1 \%(w / v)$ aqueous orthophosphoric acid was used as the mobile phase for isocratic elution. The injection volume was $3 \mu \mathrm{L}$. The flow rate was $0.44 \mathrm{~mL} / \mathrm{min}$. The temperature was set at $18^{\circ} \mathrm{C}$. The detection wavelength was $215 \mathrm{~nm}$. The analytes were identified by comparison on their retention times and UV spectra with that of the reference standards. The standard stock solutions for calibration were prepared in triplicate in methanol and serially diluted (in two replicates) with the same solvent to six concentration levels within the range of approximately $1.5-150.0 \mu \mathrm{g} / \mathrm{mL}$ for OA and 3.0-325.0 $\mathrm{\mu g} / \mathrm{mL}$ for UA. Each extract and standard samples were directly injected into the UHPLC system in triplicate. Results were calculated in $\mathrm{mg}$ per $\mathrm{g}$ of dry weight of the plant material.

\subsection{Biological Activity Testing}

\subsubsection{Hyaluronidase Inhibition Test}

Inhibitory activity of the tested analytes (extracts and individual compounds) was determined by turbidimetric method adapted for 96-well microtiter plates as described previously [52]. The protocol was started by adding $20 \mu \mathrm{L}$ of the tested analyte solution in monosodium phosphate buffer $(\mathrm{pH}=7.0)$ to $40 \mu \mathrm{L}$ of hyaluronidase solution $(22.55 \mathrm{U} / \mathrm{mL})$ in monosodium phosphate buffer $(\mathrm{pH}=7.0)$ and the mixture was incubated at $37.0 \pm 0.1^{\circ} \mathrm{C}$ in the dark for $10 \mathrm{~min}$. After this time $40 \mu \mathrm{L}$ of hyaluronic acid solution $(0.03 \%, w / v)$ in monosodium phosphate buffer $(\mathrm{pH}=5.35)$ was added and the mixture was further incubated at $37.0 \pm 0.1{ }^{\circ} \mathrm{C}$ in the dark for $45 \mathrm{~min}$. Finally $300 \mu \mathrm{L}$ of bovine serum albumin solution $(0.1 \%, w / v)$ in sodium acetate buffer $(\mathrm{pH}=3.75)$ was added to the mixture and incubated in room temperature for $10 \mathrm{~min}$. Changes in turbidity were measured at $600 \mathrm{~nm}$. All analytes were tested in the concentration range of $100-1000 \mu \mathrm{g} / \mathrm{mL}$ at minimum five levels to calculate the $\mathrm{IC}_{50}$ values. At each level three independent experiments were carried out in duplicate. Heparin was used as a positive control. Activity of the tested analytes was calculated as inhibition percentage (\% Inhibition) of hyaluronidase according to the Equation (1):

$$
\%_{\text {Inhibition }}=100 \times\left(1-\left(\frac{A_{H A}-A_{A N}}{A_{H A}-A_{H Y A L}}\right)\right),
$$

where $A_{H A}$-absorbance of solution without the enzyme, $A_{H Y A L}$-absorbance of solution without the tested analyte (negative control), $A_{A N}$-absorbance of solution with the tested analyte.

\subsubsection{Lipoxygenase Inhibition Test}

Inhibitory activity of the tested analytes (extracts and individual compounds) was determined by a spectrophotometric method adjusted to a 96-well microtiter plates according to Granica et al. [53]. The protocol was started by adding $50 \mu \mathrm{L}$ of the tested analyte solution in sodium borate buffer 
( $\mathrm{pH}=9.0)$, then $50 \mu \mathrm{L}$ of linoleic acid solution $(134 \mu \mathrm{M})$ was added, followed by $50 \mu \mathrm{L}$ of lipoxygenase solution $(167 \mathrm{U} / \mathrm{mL})$ in sodium borate buffer $(\mathrm{pH}=9.0)$. The reaction mixture was vigorously shaken and changes in absorbance were measured at $234 \mathrm{~nm}$ over a period of $15 \mathrm{~min}$ with $1 \mathrm{~min}$ intervals. All analytes were tested in the concentration range of $50-1000 \mu \mathrm{g} / \mathrm{mL}$ at minimum five levels to calculate the $\mathrm{IC}_{50}$ values. At each level three independent experiments were carried out in duplicate. Indomethacin was used as a positive control. Activity of the tested analytes was calculated as inhibition percentage (\% Inhibition) of lipoxygenase according to Equation (2):

$$
\%_{\text {Inhibition }}=100 \times\left(1-\left(\frac{A_{A N}-A_{L A}}{A_{L O X}}\right)\right)
$$

where $A_{A N}$-absorbance of solution with the tested analyte, $A_{L A}$-absorbance of solution without the enzyme, $A_{L O X}$-absorbance of solution without the tested analyte (negative control). The absorbance value in the 10th minute of the reaction were used for the calculation.

\subsection{Statistical and Data Analysis}

The results were expressed as means \pm standard deviation (SD) of replicate determinations. The statistical analyses (calculation of SD, one-way analysis of variance, HSD Tukey tests and linearity studies) were performed using the Statistica12Pl software for Windows (StatSoft Inc., Krakow, Poland), with $p$ values less than 0.05 being regarded as significant.

\section{Conclusions}

This paper is the first report on the phytochemical profile and anti-inflammatory activity of the lipophilic leaf extracts of G. procumbens and Gaultheria plants in general. The study demonstrated that both petrol and chloroform extracts are rich in various lipophilic compounds. Aliphatic hydrocarbons, alcohols, and carboxylic acids dominated among the waxy substances, and ursolic and oleanolic acids among terpenoids. The simple phenols were mainly represented by methyl salicylate and methyl benzoate. The lipophilic extracts exhibited a relatively high inhibitory activity towards hyaluronidase and moderate anti-lipoxygenase potential compared to the capacity of positive standards (heparin and indomethacin), which indicated their co-responsibility for anti-inflammatory activity of the wintergreen leaves. The final activity of the extracts was arising from additive and synergistic effects of numerous components. Among pure constituents, the most anti-inflammatory active was $(6 S, 9 R)$-vomifoliol, but ursolic and oleanolic acids were recommended as analytical markers for standardization of the plant material due to the best activity-concentration relationship. Across the growing season the highest levels of the markers were accumulated between August and October, which are thus recommended as optimal for harvesting of high quality plant material under Polish climate conditions. The chemical profile of the wintergreen lipophilic leaf extracts and existing knowledge of its main components form a basis for wider application of the extracts as preventive agents against inflammation-related disorders. However, further studies would be desirable in order to clarify the toxicity, bioavailability and other biological properties of the extracts and compounds presented here.

Supplementary Materials: Supplementary materials are available online. Figure S1: GC chromatogram of G. procumbens petrol extract, Figure S2: GC chromatogram of G. procumbens chloroform extract, Figure S3: UHPLC chromatogram of G. procumbens triterpene acids fraction, Table S1: GC-MS full data for the G. procumbens dry lipophilic leaf extracts.

Acknowledgments: The authors are grateful to Medical University of Lodz for financial support (grant No. 503/3-022-01/503-31-001, 502-03/3-022-01/502-34-058, 503/3-045-01/503-31-001, 503/3-015-01/503-31-002), to Piotr Banaszczak from the Arboretum for authentication of the plant material, and to Department of Biology and Pharmaceutical Botany, Medical University of Lodz, for providing access to the UHPLC equipment.

Author Contributions: P.M. and M.A.O. conceived and designed the experiments; P.M., A.K. and W.W. performed GC-MS experiments; P.M., P.S. and E.M.-O. performed isolation and identification experiments; P.M. and M.M. performed anti-inflammatory activity experiments; A.O. and M.K. performed UHPLC experiments; P.M., M.A.O. and A.O. wrote the paper. All authors read and approved the final manuscript. 
Conflicts of Interest: The authors declare no conflict of interest.

\section{References}

1. Liu, W.R.; Qiao, W.L.; Liu, Z.Z.; Wang, X.H.; Jiang, R.; Li, S.Y.; Shi, R.B.; She, G.M. Gaultheria: Phytochemical and pharmacological characteristics. Molecules 2013, 18, 12071-12108. [CrossRef] [PubMed]

2. Nikolić, M.; Marković, T.; Mojović, M.; Pejin, B.; Savić, A.; Perić, T.; Marković, D.; Stević, T.; Soković, M. Chemical composition and biological activity of Gaultheria procumbens L. essential oil. Ind. Crop. Prod. 2013, 49, 561-567. [CrossRef]

3. Ribnicky, D.M.; Poulev, A.; Raskin, I. The determination of salicylates in Gaultheria procumbens for use as a natural aspirin alternative. J. Nutraceut. Function. Med. Foods 2003, 4, 39-52. [CrossRef]

4. Zhang, D.; Liu, R.; Sun, L.; Huang, C.; Wang, C.; Zhang, D.M.; Zhang, T.T.; Du, G.H. Anti-inflammatory activity of methyl salicylate glycosides isolated from Gaultheria yunnanensis (Franch.) Rehder. Molecules 2011, 16, 3875-3884. [CrossRef] [PubMed]

5. Zhang, T.; Sun, L.; Liu, R.; Zhang, D.; Lan, X.; Huang, C.; Xin, W.; Wang, C.; Zhang, D.; Du, G. A novel naturally occurring salicylic acid analogue acts as an anti-inflammatory agent by inhibiting nuclear factor-kappaB activity in RAW264.7 macrophages. Mol. Pharm. 2012, 9, 671-677. [CrossRef] [PubMed]

6. Xin, W.; Huang, C.; Zhang, X.; Zhang, G.; Ma, X.; Sun, L.; Wang, C.; Zhang, D.; Zhang, T.; Du, G. Evaluation of the new anti-inflammatory compound ethyl salicylate 2-O- $\beta$-D-glucoside and its possible mechanism of action. Intern. Immunopharmacol. 2013, 15, 303-308. [CrossRef] [PubMed]

7. Michel, P.; Dobrowolska, A.; Kicel, A.; Owczarek, A.; Bazylko, A.; Granica, S.; Piwowarski, J.S.; Olszewska, M.A. Polyphenolic profile, antioxidant and anti-inflammatory activity of Eastern Teaberry (Gaultheria procumbens L.) leaf extracts. Molecules 2014, 19, 20498-20520. [CrossRef] [PubMed]

8. Lytovchenko, A.; Beleggia, R.; Schauer, N.; Isaacson, T.; Leuendorf, J.E.; Hellmann, H.; Rose, J.K.; Fernie, A.R. Application of GC-MS for the detection of lipophilic compounds in diverse plant tissues. Plant Methods 2009, 5, 4. [CrossRef] [PubMed]

9. Chen, C.Y.; Lin, R.J.; Huang, J.C.; Wu, Y.H.; Cheng, M.J.; Lo, W.L. Chemical constituents from the whole plant of Gaultheria itoana Hayata. Chem. Biodivers. 2009, 6, 1737-1743. [CrossRef] [PubMed]

10. Zhang, Z.; Guo, D.; Li, C.; Zheng, J.; Koike, K.; Jia, Z.; Nikaido, T. Two diterpenoides from the roots of Gaultheria yunnanensis. J. Nat. Prod. 1999, 62, 297-298. [CrossRef] [PubMed]

11. Li, J.; Li, F.; Lu, Y.Y.; Su, X.J.; Huang, C.P.; Lu, X.W. A new dilactone from the seeds of Gaultheria yunnanesis. Fitoterapia 2010, 81, 35-37. [CrossRef] [PubMed]

12. Ma, X.J.; Du, C.F.; Zheng, J.H.; Chen, X.Z. Studies of chemical constituents of Gaultheria leucocarpa var. yunnanensis. Zhongguo Zhonoyao Zazhi (Chin. J. Chin. Mat. Med.) 2001, 26, 844-846.

13. Yang, M.F.; Li, Y.Y.; Li, B.G.; Zhang, G.L. A novel alkaloide from Gaultheria nummularioides. J. Asian Nat. Prod. Res. 2007, 9, 183-186. [CrossRef] [PubMed]

14. Eglinton, G.; Hamilton, R.J.; Martin-Smith, M. The alkane constituents of some New Zealand plants and their possible taxonomic implications. Phytochemistry 1962, 1, 137-145. [CrossRef]

15. Córdova, C.; Gutiérrez, B.; Martínez-García, C.; Martín, R.; Gallego-Muñoz, P.; Hernández, M.; Nieto, M.L. Oleanolic acid controls allergic and inflammatory responses in experimental allergic conjunctivitis. PLoS ONE 2014, 9, e91282. [CrossRef] [PubMed]

16. Lee, W.; Yang, E.J.; Song, K.S.; Bae, J.S. Anti-inflammatory effects of oleanolic acid on LPS-induced inflammation in vitro and in vivo. Inflammation 2013, 36, 94-102. [CrossRef] [PubMed]

17. Checker, R.; Sandur, S.K.; Sharma, D.; Patwardhan, R.S.; Jayakumar, S.; Kohli, V.; Sethi, G.; Aggarwal, B.B.; Sainis, K.B. Potent anti-inflammatory activity of ursolic acid, a triterpenoid antioxidant, is mediated through suppression of NF-kB, AP-1 and NF-AT. PLoS ONE 2012, 7, e31318. [CrossRef] [PubMed]

18. Ikeda, Y.; Murakami, A.; Ohigashi, H. Ursolic acid: An anti- and pro-inflammatory triterpenoid. Mol. Nutr. Food Res. 2008, 52, 26-42. [CrossRef] [PubMed]

19. Vázquez, L.H.; Palazon, J.; Navarro-Ocaña, A. The pentacyclic triterpenes-Amyrins: A review of sources and biological activities. In Phytochemicals - A Global Perspective of Their Role in Nutrition and Health; In Tech: Rijeka, Croatia, 2012.

20. Loizou, S.; Lekakis, I.; Chrousos, G.P.; Moutsatsou, P. $\beta$-Sitosterol exhibits anti-inflammatory activity in human aortic endothelial cell. Mol. Nutr. Food Res. 2010, 54, 551-558. [CrossRef] [PubMed] 
21. Michel, P.; Owczarek, A.; Kosno, M.; Gontarek, D.; Matczak, M.; Olszewska, M.A. Variation in polyphenolic profile and in vitro antioxidant activity of eastern teaberry (Gaultheria procumbens L.) leaves following foliar development. Phytochem. Lett. 2017, in press. [CrossRef]

22. Soni, U.; Brar, S.; Gauttam, V.K. Effect of seasonal variation on secondary metabolites of medicinal plants. IJPSR 2015, 6, 3654-3662.

23. Markham, K.R.; Geiger, H. ${ }^{1} \mathrm{H}$ Nuclear Magnetic Resonance spectroscopy of flavonoids and their glycosides in hexadeuterodimethylsulfoxide. In The Flavonoids. Advances in Research Since 1986; Harborne, J.B., Ed.; Chapman \& Hall: Cambridge, UK, 1994; pp. 441-498.

24. Mabry, T.J.; Markham, K.R.; Thomas, M.B. The Systematic Identification of Flavonoids; Springer: Berlin/Heidelberg, Germany; New York, NY, USA, 1970.

25. Li, Y.L.; Wu, L.; Ouyang, D.W.; Yu, P.; Xia, J.H.; Pan, Y.X.; Yang, X.W.; Zeng, H.W.; Cheng, X.R.; Jin, H.Z.; et al. Phenolic compounds of Abies nephrolepis and their NO production inhibitory activities. Chem. Biodivers. 2011, 8, 2299-2309. [CrossRef] [PubMed]

26. Wollenweber, E.; Kohorst, G. Novel epicuticular leaf flavonoids from Kalmia and Gaultheria (Ericaceae). Z. Naturforsch. 1984, 39C, 710-713.

27. Junio, H.A.; Sy-Cordero, A.A.; Ettefagh, K.A.; Burns, J.T.; Micko, K.T.; Graf, T.N.; Richter, S.J.; Cannon, R.E.; Oberlies, N.H.; Cech, N.B. Synergy-directed fractionation of botanical medicines: A case study with Goldenseal (Hydrastis canadensis). J. Nat. Prod. 2011, 74, 1621-1629. [CrossRef] [PubMed]

28. Banfi, D.; Patiny, L. www.nmrdb.org: Resurrecting and processing NMR spectra on-line. Chimia 2008, 62, 280-281. [CrossRef]

29. Yamano, Y.; Ito, M. Synthesis of optically active vomifoliol and roseoside stereoisomers. Chem. Pharm. Bull. 2005, 53, 541-546. [CrossRef] [PubMed]

30. Dalla Serra, A.; Franco, M.A.; Mattivi, F.; Ramponi, M.; Vacca, V.; Versini, G. Aroma characterization of Sardinian strawberry tree (Arbutus unedo L.) honey. Ital. J. Food Sci. 1999, 11, 47-56.

31. Amakura, Y.; Yoshimura, M.; Sugimoto, N.; Yamazaki, T.; Yoshida, T. Marker constituents of the natural antioxidant Eucalyptus leaf extract for the evaluation of food additives. Biosci. Biotechnol. Biochem. 2009, 73, 1060-1065. [CrossRef] [PubMed]

32. Libby, P. Inflammatory mechanisms: The molecular basis of inflammation and disease. Nutr. Rev. 2007, 65, 140-146. [CrossRef]

33. Souza, M.T.; Almeida, J.R.; Araujo, A.A.; Duarte, M.C.; Gelain, D.P.; Moreira, J.C.; dos Santos, M.R.; Quintas-Júnior, L.J. Structure-activity relationship of terpenes with anti-inflammatory profile-A systematic review. Basic Clin. Pharmacol. Toxicol. 2014, 115, 244-256. [CrossRef] [PubMed]

34. Han, N.; Bakovic, M. Biologically active triterpenoids and their cardioprotective and anti-inflammatory effects. J. Bioanal. Biomed. 2015, S12, 005.

35. Yadav, V.R.; Prasad, S.; Sung, B.; Kannappan, R.; Aggarwal, B.B. Targeting inflammatory pathways by triterpenoids for prevention and treatment of cancer. Molecules 2010, 2, 2428-2466. [CrossRef] [PubMed]

36. Woźniak, L.; Skapska, S.; Marszałek, K. Ursolic acid-A pentacyclic terpenoid with a wide spectrum of pharmacological activities. Molecules 2015, 20, 20614-20641. [CrossRef] [PubMed]

37. Ogbe, R.J.; Ochalefu, D.O.; Mafulul, G.; Olaniru, O.B. A review on dietary phytosterols: Their occurrence, metabolism and health benefits. Asian J. Plant Sci. Res. 2015, 5, 10-21.

38. Chua, T.; Eise, N.T.; Simpson, J.S.; Ventura, S. Pharmacological characterization and chemical fractionation of a liposterolic extract of saw palmetto (Serenoa repens): Effects on rat prostate contractility. J. Ethnopharmacol. 2014, 152, 283-291. [CrossRef] [PubMed]

39. Gutierrez, R.M.P. Review of Cucurbita pepo (pumpkin) its phytochemistry and pharmacology. Med. Chem. 2016, 6, 12-21. [CrossRef]

40. Kadu, C.A.C.; Parich, A.; Schueler, S.; Konrad, H.; Muluvi, G.F.; Eyog-Matig, O.; Muchugi, A.; Williams, V.L.; Ramamonjisoa, L.; Kapinga, C.; et al. Bioactive constituents in Prunus africana: Geographical variation throughout Africa and associations with environmental and genetic parameters. Phytochemistry 2012, 83, 70-78. [CrossRef] [PubMed]

41. Rajasree, R.S.; Sibi, P.I.; Francis, F.; William, H. Phytochemicals of Cucurbitaceae family-A review. IJPPR 2016, 8, 113-123.

42. Keehn, A.; Taylor, J.; Lowe, F.C. Phytotherapy for benign prostatic hyperplasia. Curr. Urol. Rep. 2016, 17, 53. [CrossRef] [PubMed] 
43. Alonso, D.L.; Maroto, F.G. Plants as 'chemical factories' for the production of polyunsaturated fatty acids. Biotechnol. Adv. 2000, 18, 481-497. [CrossRef]

44. Simopoulos, A.P. Omega-3 fatty acids in inflammation and autoimmune diseases. J. Am. Coll. Nutr. 2002, 21, 495-505. [CrossRef] [PubMed]

45. Owczarek, A.; Kuźma, Ł.; Wysokińska, H.; Olszewska, M.A. Application of response surface methodology for optimisation of simultaneous UHPLC-PDA determination of oleanolic and ursolic acids and standardisation of Ericaceae medicinal plants. Appl. Sci. 2016, 6, 244. [CrossRef]

46. Jäger, S.; Trojan, H.; Kopp, T.; Laszczyk, M.N.; Scheffler, A. Pentacyclic triterpene distribution in various plants-Rich sources for a new group of multi-potent plant extracts. Molecules 2009, 14, 2016-2031. [CrossRef] [PubMed]

47. Szakiel, A.; Mroczek, A. Distribution of triterpene acids and their derivatives in organs of cowberry (Vaccinium vitis-idaea L.) plant. Acta Biochim. Pol. 2007, 54, 733-740. [PubMed]

48. Szakiel, A.; Paczkowski, C.; Koivuniemi, H.; Huttunen, S. Comparison of the triterpenoid content of berries and leaves of lingonberry Vaccinium vitis-idaea from Finland and Poland. J. Agric. Food Chem. 2012, 60, 4994-5002. [CrossRef] [PubMed]

49. Szakiel, A.; Pączkowski, C.; Huttunen, S. Triterpenoid content of berries and leaves of bilberry Vaccinium myrtillus from Finland and Poland. J. Agric. Food Chem. 2012, 60, 11839-11849. [CrossRef] [PubMed]

50. Wójciak-Kosior, M.; Nowak, R.; Sokołowska-Krzaczek, A.; Pietrzak, W.; Sowa, I.; Kocjan, R. Determination of oleanolic and ursolic acid in billberies (Vaccinium myrtillus L.). Curr. Issues Pharm. Med. Sci. 2012, 25, 146-148. [CrossRef]

51. Rogachev, A.D.; Komarova, N.I.; Morozov, S.V.; Fomenko, V.V.; Salakhutdinov, N.F. Phytochemical studies of Rhododendron adamsii Rehder. Quantitative determination of ursolic and oleanolic acids in some representatives of Ericaceae family. Chem. Suistain. Dev. 2007, 15, 561-564.

52. Piwowarski, J.; Kiss, A.K.; Kozłowska-Wojciechowska, M. Anti-hyaluronidase and anti-elastase activity screening of tannin-rich plant materials used in traditional Polish medicine for external treatment of diseases with inflammatory background. J. Ethnopharmacol. 2011, 137, 937-941. [CrossRef] [PubMed]

53. Granica, S.; Czerwińska, M.E.; Piwowarski, J.P.; Ziaja, M.; Kiss, A.K. Chemical composition, antioxidant and anti-inflammatory activity of extracts prepared from aerial parts of Oenothera biennis L. and Oenothera paradoxa Hudziok obtained after seed cultivation. J. Agric. Food Chem. 2016, 61, 801-810. [CrossRef] [PubMed]

Sample Availability: Samples of the dry leaf extracts are available from the authors.

(C) 2017 by the authors. Licensee MDPI, Basel, Switzerland. This article is an open access article distributed under the terms and conditions of the Creative Commons Attribution (CC BY) license (http:/ / creativecommons.org/licenses/by/4.0/). 